\title{
Reproductive toxicity assessment of Olusosun municipal landfill leachate in Mus musculus using abnormal sperm morphology and dominant lethal mutation assays
}

\author{
Olaoluwa J. Ademola', Chibuisi G. Alimba ${ }^{2,3}$, Adekunle A. Bakare ${ }^{2}$ \\ 'Department of Zoology, University of Ilorin, Ilorin, Nigeria; ${ }^{2}$ Cell Biology and Genetics Unit, Department of Zoology, University of Ibadan, Ibadan, \\ Nigeria; ${ }^{3}$ Leibniz Research Centre for Working Environment and Human Factors (IfADo), Technical University of Dortmund, Dortmund, Germany.
}

\begin{abstract}
Mixture of xenobiotics in Olusosun landfill leachates (OSL) induced somatic and germ cell genotoxicity in eukaryotic cells. However, whether the DNA-damaged germ cells can increase reproductive failure, embryotoxicity and/or teratogenicity during fertilization remained unclear. The study herein investigated reproductive toxicity and embryotoxic effects of OSL in mice using abnormal sperm morphology and dominant lethal mutation assays. Six mice per group were exposed to $0.5 \mathrm{~mL}$ of 5, 10, 25, and 50\% OSL (v/v, leachate/distilled water) for 5 consecutive days. Similar treatment was giving to distilled water and cyclophosphamide (20 mg/kg body weight), as negative and positive control groups, respectively. At 35 day post-treatment, the mice were sacrificed and examined for cauda epididymal abnormal sperm morphology, testicular weight change and histopathological lesions. Male mice were mated to untreated nulliparous females ( 1 treated male per 2 untreated females) until vaginal plugs were observed. Pregnant females were sacrificed on 14th day post-mating and uterine content examined for number of implants per female, resorptions, and live and dead fetuses. OSL significantly increased teratozoospermia by $31.02 \%$ with amorphous sperm head having the highest frequency and sperm with two heads, the least. Histology of the testes revealed congestion of the interstitial blood vessels, spermatid retention and disorganization of the germinal epithelium from the basal compartment. OSL insignificantly increased absolute and relative testes weights but reduced body weight of exposed mice. There was insignificant induction of dominant lethal mutation, although low fertility was observed in the treated mice. The analyzed physico-chemical parameters and heavy metals/ metalloids in OSL were higher than permissible limits. The metals, physico-chemical parameters and other unanalyzed substances in OSL induced abnormal sperm morphology, altered testes pathology, but did not significantly induce dominant lethal mutation in mice. Constituents of OSL are toxic to the male reproductive organs in mice and suggests harmful impact on public health. Indiscriminate disposal of solid wastes in the environment should be prevented.
\end{abstract}

Keywords: abnormal sperm morphology, dominant lethal mutation, histopathology, Olusosun landfill leachate, Mus musculus

\section{Introduction}

Anthropogenic activities generate wastes, but inappropriate management of these wastes causes major public health and environmental contamination issues. These issues increase with human population and industrial activities [1,2]. Landfilling, the most common method of managing solid wastes around the world, causes nuisance to the environment via the

Received: May 6, 2020 Accepted: June 4, 2020

Corresponding author: Chibuisi G. Alimba

Cell Biology and Genetics unit, Department of Zoology, University of Ibadan, Ibadan, Nigeria

Leibniz Research Centre for Working Environment and Human Factors (IfADo),

Technical University of Dortmund, Dortmund, Germany

E-mail: cg.alimba@ui.edu.ng, chivoptera@yahoo.com

This article is available from: http://e-eht.org/ release of chemical laden landfill gases and leachates. Njoku et al. reported enormous evidence linking exposure to solid waste chemicals with human and wildlife health challenges for over four decades [3].

Olusosun landfill, an unsanitary and the largest dumpsite in Africa [4], receives over 1.0 million tons of solid wastes per annum. These wastes are generated from various human activities in Lagos State, Nigeria [5]. The dumpsite, which is located in the public domain and surrounded by residential quarters, generates and discharges landfill gases and leachates into the environment [6,7]. Leachates generated from Olusosun landfill solid wastes contain microorganisms, hazardous organic and inorganic chemicals including heavy metals and radiations [812]. These xenobiotics can contaminate surrounding underground and surface water, soil and air, posing threat to human 
health. Previous studies showed that multiple xenobiotics in Olusosun landfill leachate (OSL) increased chromosome aberration and micronucleus formation in somatic cells of vertebrates inhabiting various ecological habitats and induced DNA damage and cytotoxicity in three human cell lines $[6,11,12]$. Similarly, Bakare et al. showed that landfill leachate increased abnormal sperm morphology in cauda epididymis of exposed mice [13]. The reports on somatic and germ cell genotoxicity induced by complex mixture of xenobiotics in landfill leachates suggest increased mutation frequency that may be associated with increased outcome of reproductive disorder and fitness instability [14]. Whether the abnormal sperm cells formed during exposure to landfill leachate are associated with reproductive failure, embryotoxicity and/or teratogenic effects in human and animal models is yet to be studied.

The outcome of studies investigating reproductive failure in rodents exposed to landfill leachates may be useful in understanding how humans residing and working within $2-3 \mathrm{~km}$ radius of landfill facilities expressed high incidence of low birth weight, different congenital malformations, adverse pregnancy outcomes and other reproductive or developmental anomalies $[3,15,16]$. In the study herein, a dominant lethal test, an assay that detects mutagens capable of increasing male germ cell mutation during spermatogenesis, embryonic viability and/or present risk of transmissible genetic damage [17], was used to evaluate embryonic viability in female mice mated with leachate exposed male mice. The study utilizes the sperm head abnormality and dominant lethal mutation test as biomarkers to assess the potentials of OSL to increase reproductive abnormalities and reduce embryonic viability in mice.

\section{Materials and methods}

\section{Sampling site, leachate collection and processing}

The sampling site, Olusosun landfill, Lagos State, Nigeria $\left(6^{\circ} 34^{\prime} \mathrm{N}^{\circ} 24^{\prime} \mathrm{E}\right)$ is the largest landfill in Nigeria covering 42 hectares of land with a life span of 35 years from inception in 1999 [18]. Raw leachate was collected from 20 different leachate wells within the landfill and thoroughly mixed to obtain a homogenous mixture [7]. This sample was transferred to the laboratory, in a pre-cleaned $10 \mathrm{~L}$ transparent plastic container for the subsequent experiment. The leachate sample was aliquoted for analysis of the physico-chemical parameters and heavy metal composition. The other aliquot was used for the animal experiment. The aliquot for the animal experiment was filtered with a glass wool and Whatmann ${ }^{\circledR}$ No. 42 filter paper to remove suspended particles $[7,19]$. The resultant filtrate was centrifuged at $600 \mathrm{~g}$ for 15 minutes and the supernatant used as stock solution (100\% OSL). 5, 10, 25, and 50\% solutions were prepared from the stock solution based on previous studies $[7,20]$ using distilled water (v/v, leachate/distilled water) as diluent and kept at $4^{\circ} \mathrm{C}$.

Physico-chemical and heavy metal analyses of the leachate The physico-chemical parameters; nitrate, ammonia, chloride, phosphate, sulphate, total hardness, total alkalinity, biochemical oxygen demand (BOD), chemical oxygen demand (COD), total solids (TS) and concentration of heavy metals: iron $(\mathrm{Fe})$, lead $(\mathrm{Pb})$, copper $(\mathrm{Cu})$, manganese $(\mathrm{Mn})$, arsenic (As), cadmium (Cd), and mercury (Hg), present in OSL were analyzed in accordance with standard analytical methods $[21,22]$.

Animal acclimatization and leachate exposure regimen

Male and female mice between 10- to 12-week-old with body weight range of 18.6-25.1 g, obtained from the Animal facility of the Department of Zoology, University of Ibadan, were used. They were acclimatized to laboratory conditions of 12 hours light/dark cycle for two weeks and allowed access to food and water ad libitum. $0.5 \mathrm{~mL}$ of the various OSL concentrations; $5,10,25$, and $50 \%$ were intraperitoneally injected into each mouse in a group of 6 male mice for 5 consecutive days. Negative (distilled water) and positive (cyclophosphamide, 20 $\mathrm{mg} / \mathrm{kg}$ body weight) control groups received same treatment [23]. Cyclophosphamide, an alkylating agent, was selected as the positive control due to its ability to significantly induce abnormal sperm cells and subsequently increase dominant lethal mutations in mammalian systems $[55,56]$. The treated and control mice were sacrificed at 5 weeks of post-treatment, this is to allow for a complete spermatogenic cycle of 34.5 days in mice [24]. The body weight of the mice was recorded before and at the termination of the experiment using Acculab ${ }^{\circledR}$ USA, Model-vic-303 electronic analytical weighing balance (Sycamore, IL, USA). Percentage body weight gain was determined using equation (1).

$$
\frac{\text { Final body weight-Initial body weight }}{\text { Initial body weight }} \times 100
$$

International standard guide for care and use of laboratory animals in accordance with the US National Institute of Health (NIH Publication No. 85-23, revised in 1996) was strictly adhered during the experiment.

\section{Sperm head abnormality assay and testis histopathological} analysis

At post-exposure, the control and OSL treated mice were sacrificed and their testes surgically excised, rinsed in phosphate buffered saline (pH 7.4), blotted in Whatmann ${ }^{\circledR}$ No. 42 
filter paper and absolute weight measured. Relative testes weight was determined from the absolute weight using the formula:

$$
\text { Relative testes weight }=\frac{\text { Absolute testes weight }}{\text { Final body weight }}
$$

The right testis from each mouse was fixed in Bouin's fluid for histopathological analysis. The cauda epididymis was surgically removed for abnormal sperm morphology test, which was carried out in accordance with standard procedure [24]. The cauda epididymis was minced in physiological saline using fine needle to produce sperm suspension. The suspension was stained using $1 \%$ eosin Y (9:1, physiological saline/eosin Y) for 45 minutes and 6 slides prepared per mouse, air-dried and blind coded for microscopic analysis. A thousand of sperm cells per mouse were assessed for abnormal sperm head morphology in accordance with Wyrobek et al. [24] .

Bouin's fluid fixed testes were processed and slides prepared for Haematoxylin-Eosin (H-E) staining. The tissues were dehydrated in ascending order of ethyl alcohol-water concentrations, cleared in xylene and sequentially embedded in paraffin wax blocks using rotary microtome. Tissue sections of 3-5 $\mu \mathrm{m}$ thick were cut and prepared on clean slides for H-E staining and mounted in neutral DPX, mounting medium for pathological assessment, using light microscope at $400 \times$ and $100 \times$ magnification.

\section{Dominant lethal assay}

The male mice from OSL-treated and control groups were used for the dominant lethal test in accordance with the protocol by the Organization of Economic Co-operation and Development (OECD) [23]. At the end of 35-day exposure, a treated male was mated to 2 untreated nulliparous (virgin) females un- til vaginal plug (indication of the congealed contents of the seminal fluid) was observed in the females (Figure 1A), usually within 2-3 days. The mated females were then isolated into separate cages and labeled according to the treatment groups. At pregnancy day 14, the females were sacrificed and the uterus contents were examined for the number and status of implantation site (Figure 1B and 1C). The total number of implants, number of live implants, number of early resorptions or moles and late death were recorded at the time of dissection of each mouse [23] (Figure 1B and 1C). The frequency of induced dominant lethal mutations was determined and expressed as percentage of the dominant lethality using the formula below:

$\left(1-\frac{\text { live implants per female in the treatment group }}{\text { live implants per female in the negative control group }}\right) \times 100$

\section{Statistical analysis}

Data were analyzed using Graphpad prism $5.0^{\circledR}$ computer software. One-way analysis of variance (ANOVA) was used to determine the significant difference among the various groups for the body weight gain and the absolute and relative testis weight, and abnormal sperm morphology. Dunnett multiple posthoc-test (DMPT) was used to compare the level of significance $(\mathrm{p}<0.05)$ of each treated group with the negative control. Difference between the negative control and each treatment group for the dominant lethality was analyzed using the Student's $t$-test at $\mathrm{p}<0.05$.

\section{Results}

\section{Physico-chemical properties of Olusosun landfill leachates sample}

The analysis of physico-chemical parameters and concentra-


Figure 1. (A) A female mouse showing vaginal plug which is an indication of pregnancy. (B, C) The total number of implants and number of live implants. (d) Red arrow points at resorbed foetus in Olusosun landfill leachate (OSL)-exposed mouse. 
tion of heavy metals in OSL are presented on Table 1. OSL which was foul smelling and in brown colour was slightly alkaline ( $\mathrm{pH}$ 7.5). The analyzed parameters - BOD, COD, TDS and concentration of chlorides, phosphate, $\mathrm{Fe}, \mathrm{Cu}, \mathrm{Pb}, \mathrm{Hg}, \mathrm{Mn}, \mathrm{As}$, and $\mathrm{Cd}$ - were higher than standard permissible limits from National Environmental Standards and Regulations Enforcement Agency (NESREA) in Nigeria and United States Environmental Protection Agency (USEPA). However, alkalinity and concentration of sulphate and nitrate were below the limits set

Table 1. Physico-chemical parameters and concentration of heavy metals analyzed in Olusosun landfill leachate (OSL)

\begin{tabular}{lccc}
\hline Parameters $^{\mathrm{a}}$ & OSL & NESREA $^{\mathrm{e}}$ & USEPA $^{\dagger}$ \\
\hline $\mathrm{pH}$ & 7.5 & $6.0-9.0$ & $6.5-8.5$ \\
Colour & Brown & - & - \\
Alkalinity & 2.2 & 150 & 20 \\
Hardness & 75.7 & - & $0-75$ \\
BOD $^{\mathrm{b}}$ & 1,315 & 50 & - \\
COD $^{\mathrm{c}}$ & 2,650 & 90 & - \\
TDS $^{\mathrm{d}}$ & 920 & - & - \\
Chlorides $_{\text {Sulphates }}$ & 2,450 & 250 & 250 \\
Nitrates & 4.2 & 250 & 250 \\
Ammonia & 6.5 & 10 & 10 \\
Copper (Cu) & 1.3 & 10 & 0.02 \\
Iron (Fd) & 11.3 & 0.5 & 1.3 \\
Lead (Pb) & 2.43 & - & 0.3 \\
Cadmium (Cd) & 0.4 & 0.05 & 0.015 \\
Manganese (Mn) & 0.19 & 0.2 & 0.05 \\
Arsenic (As) & 0.82 & 0.2 & 0.05 \\
Mercury (Hg) & 0.3 & - & 0.01 \\
\hline
\end{tabular}

${ }^{a)}$ All values are in $\mathrm{mg} / \mathrm{L}$ except $\mathrm{pH}$; ${ }^{\mathrm{b}} \mathrm{BOD}$ : Biochemical oxygen demand; ${ }^{\mathrm{c}} \mathrm{COD}$ :

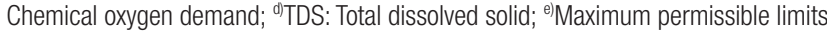
for wastewater set by National Environmental Standards and Regulation Enforcement Agency (NESREA) (2011); 'United States Environmental Protection Agency (USEPA) (2006). by these standards, hardness was within the range of the limits while ammonia was higher than permissible limit of USEPA, but below NESREA permissible limit.

\section{Percentage body weight gain and testes weight of mice treated with OSL and the controls}

Change in body weight showed that body weight of mice treated with OSL decreased compared to the negative control. However, this was not significant $(\mathrm{p}=0.6913$; $\mathrm{r}=0.4516$ ) (Table 2). Also, the absolute and relative testes weight increased in the exposed mice, howbeit these were not statistically significant compared with the negative control; absolute $(\mathrm{p}=0.1182$, $\mathrm{r}=0.6941)$ and relative $(\mathrm{p}=0.1633, \mathrm{r}=0.6673)$ (Figure 2).

\section{Abnormal sperm morphology analyzed in the Olusosun landfill leachates treated and control mice}

OSL significantly ( $p>0.05)$ increased the frequency of abnormal spermatozoa in the treated mice compared to the negative control (Figure 3). Abnormal spermatozoa increased 2.53-,

Table 2. Change in body weight of mice exposed to Olusosun landfill leachate (OSL)

\begin{tabular}{lccc}
\hline $\begin{array}{c}\text { OSL Concentration } \\
(\%)\end{array}$ & $\begin{array}{c}\text { Initial body weight } \\
(\mathrm{g})\end{array}$ & $\begin{array}{c}\text { Final body weight } \\
(\mathrm{g})\end{array}$ & $\begin{array}{c}\text { Body weight gain } \\
(\%)\end{array}$ \\
\hline Control & $18.53 \pm 1.42$ & $26.47 \pm 3.25$ & 42.85 \\
5 & $21.53 \pm 0.83$ & $28.47 \pm 2.43$ & 32.23 \\
10 & $23.33 \pm 1.88$ & $29.17 \pm 1.71$ & 24.99 \\
25 & $19.87 \pm 1.09$ & $27.67 \pm 1.46$ & 39.26 \\
50 & $20.27 \pm 0.54$ & $26.90 \pm 0.96$ & 32.71 \\
Cyp $^{\mathrm{a}}$ & $21.57 \pm 2.22$ & $28.87 \pm 0.40$ & 33.84
\end{tabular}



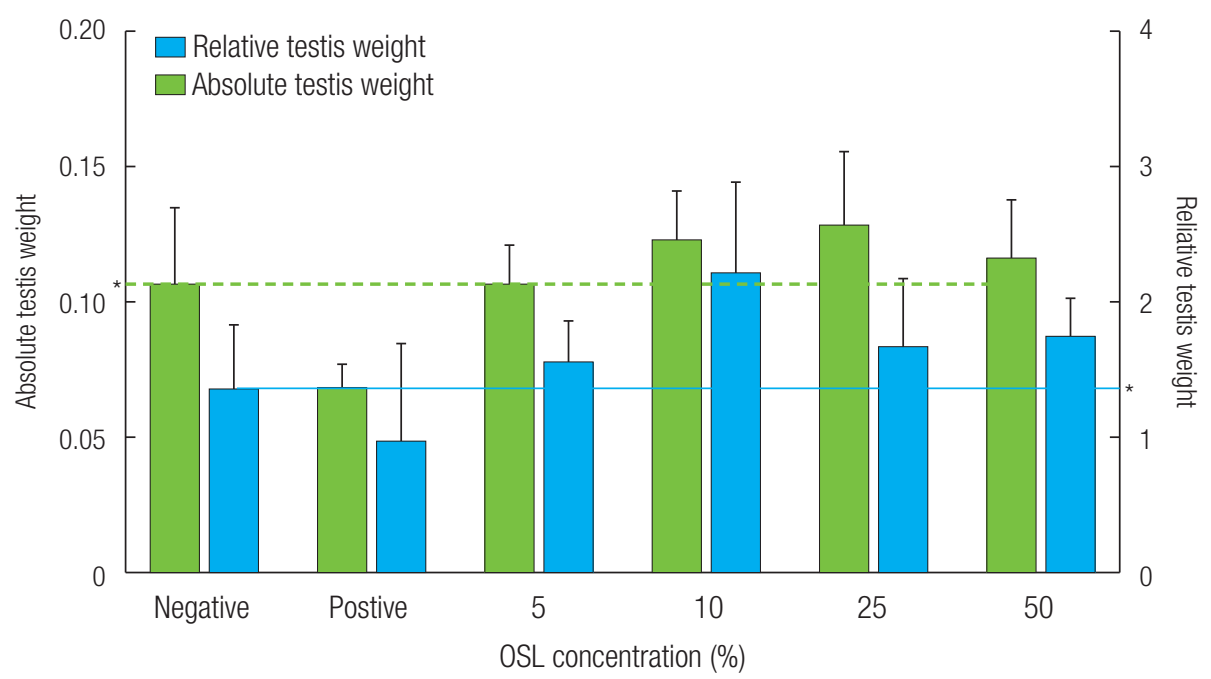

Figure 2. Absolute $(p=0.1182)$ and relative $(p=0.1633)$ testes weight measured in mice exposed to Olusosun landfill leachate (OSL) compared with the negative control. Negative (Distilled water) and positive (cyclophosphamide; 20 mg/kg) controls. 




Figure 3. Frequency of sperms with abnormal morphology and the percentage occurrence of abnormal spermatozoa induced in Olusosun landfill leachate (OSL)-exposed mice. ${ }^{*} \mathrm{p}<0.05,{ }^{* *} \mathrm{p}<0.01,{ }^{* * *} \mathrm{p}<0.001$ compared to negative control.

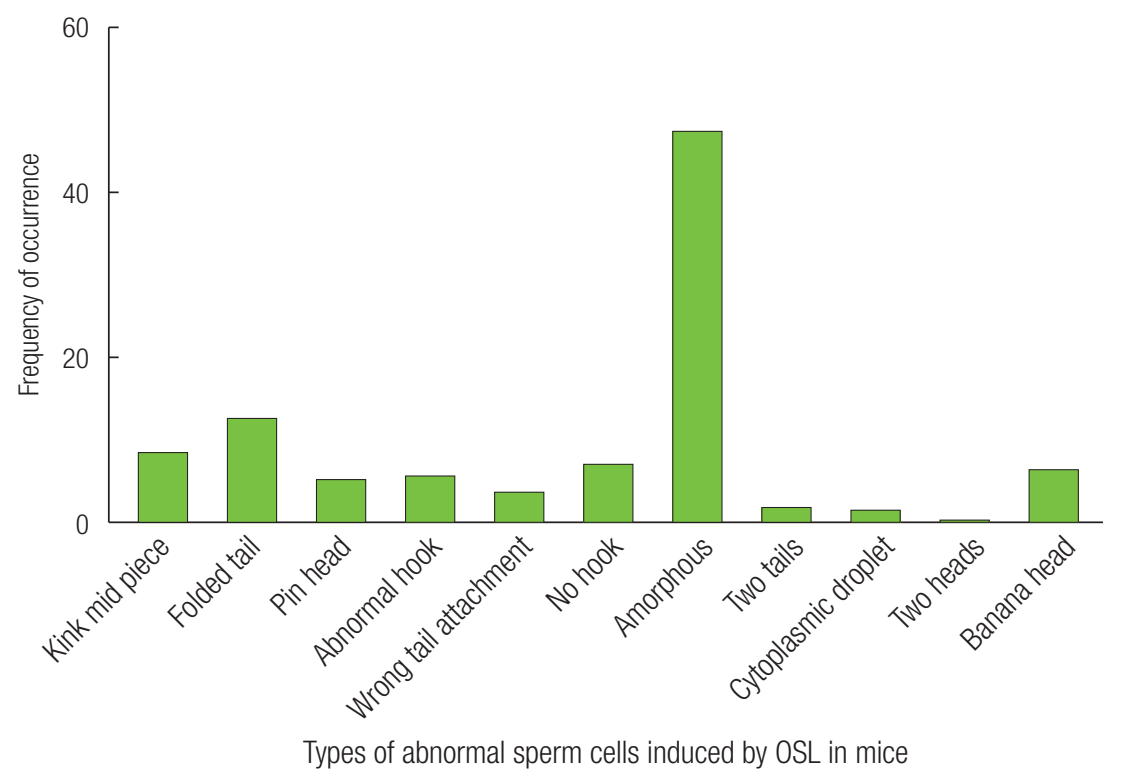

Figure 4. Frequency of occurrence of the various abnormal spermatozoa observed in Olusosun landfill leachate (OSL)-treated mice.

8.50-, 8.88- and 13.43-fold in 5, 10, 25, and 50\% of OSL treated mice, respectively, which revealed concentration dependence. Frequency of the type of abnormal spermatozoa induced by OSL in the treated mice showed that amorphous head spermatozoon with $47.68 \%$ was the highest while spermatozoa with two heads scoring $0.34 \%$ are the least induced type of sperm abnormalities (Figure 4). Other abnormal sperm morphology induced in OSL-treated mice include cytoplasmic droplet, sperm without hook, two tail sperm cell, wrong tail attachment on the head, folded, banana and pin head (Figure 5). Histological structure of the testis from the negative control mice presents numerous uniformly sized seminiferous tubules with regular architectures. Also, there were moderate quantity of spermatogenic cells with widened luminal spaces, predominant spermatocytes with scanty numbers of elongated (late stage) spermatids and small quantity of interstitial cells (Figure 6A). However, testicular architecture of OSL-treated mice presents numerous interstitial cells, congestion of the interstitial blood vessels (vascular congestion), spermatid retention, disorganization of the germinal epithelium from the basal compartment into the lumen of the seminiferous tubules and variations in height and width of the seminiferous tubule lumen (Figure 6B-6D).

\section{Dominant lethal analysis}

Frequency of dominant lethality in female mice mated with 



Figure 5. Abnormal spermatozoa induced in mice exposed to Olusosun landfill leachate (OSL). (A) Normal spermatozoon. (B) Spermatozoon with cytoplasmic droplet at the mid piece. (C) Spermatozoon without hook. (D) Spermatozoon with two heads. (E) Spermatozoon with two tails. (F). spermatozoon with wrong tail attachment to the head. (G) Folded spermatozoon. (H) Spermatozoon with abnormal hook. (I) Spermatozoon with short hook. (J) Spermatozoon with banana head and without hook. (K) Spermatozoon with amorphous head. (L) Spermatozoon with pin head. (M) Spermatozoon with kink or bent tail. (N) Spermatozoon with short hook and cytoplasmic droplet at the mid piece. (0) Spermatozoon with wrong tail attachment and without hook. Mag. $\times 1,000$.
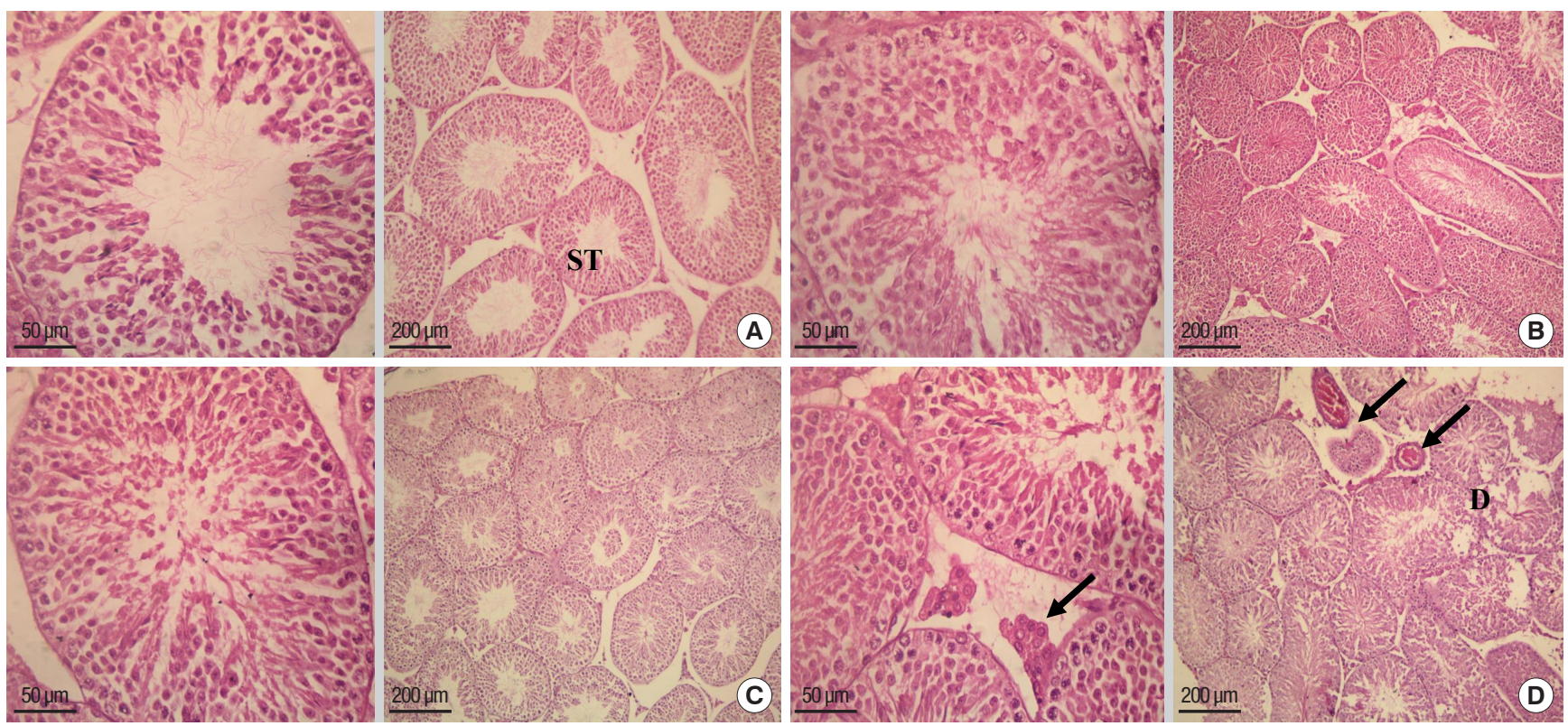

Figure 6. (A) Section of testis from the negative control mouse showing seminiferous tubule (ST) with an apparently normal luminal space and regular outlines. There are moderate amounts of spermatogenic cells, predominant spermatocytes and scanty number of elongate (late-stage) spermatids. Also there are little amounts of interstitial cells. Mag. $\times 200 \mu \mathrm{m}$ and $50 \mu \mathrm{m}$. (B) Section from 5\% OSL treated mouse showing numerous uniformly-sized STs with regular outlines. There are numerous spermatogenic cells (increased height of spermatogenic epithelium), which almost obscure the luminal space in some STs. There are sufficient numbers of spermatocytes as well as early and late-stage spermatids. Mag.×200 $\mu \mathrm{m}$ and $50 \mu \mathrm{m}$. (C) Section from 10\% OSL treated mouse showing numerous, large and regular STs. STs contain moderate amounts of spermatogenic cells with mild increased height of germinal epithelium. Numerous mitoses observed at the basal compartment of the STs. There are predominant spermatocytes and late-stage spermatids with numerous interstitial cells. Mag. $\times 200 \mu \mathrm{m}$ and $50 \mu \mathrm{m}$. (D) There are numerous, closely-packed, large STs with regular outlines which contain densely packed numerous spermatogenic cells (increased height of spermatogenic epithelium) which almost obscure the luminal space in some STs. Spermatocytes predominated with frequent latestage spermatids. There are moderate congestion of interstitial blood vessels (black arrow). Also there was disorganisation of the ST epithelium (D). Mag. $\times 200$ $\mu \mathrm{m}$ and $50 \mu \mathrm{m}$. 
Olaoluwa J. Ademola, et al. I Landfill leachate reproductive toxicity dominant lethality mice

Table 3. Summary of the results of the dominant lethal test on male mice treated with Olusosun landfill leachate (OSL)

\begin{tabular}{|c|c|c|c|c|c|c|c|c|c|c|}
\hline \multirow{2}{*}{$\begin{array}{l}\text { OSL } \\
\text { Concentration (\%) }\end{array}$} & \multicolumn{2}{|c|}{ Pregnant female mice } & \multicolumn{2}{|c|}{ Total implants } & \multicolumn{2}{|c|}{ Live implants } & \multicolumn{2}{|c|}{ Dead implants ${ }^{b}$} & \multirow{2}{*}{$\begin{array}{c}\text { Dead } \\
\text { implants per } \\
\text { female (\%) }\end{array}$} & \multirow{2}{*}{$\begin{array}{l}\text { Dominant } \\
\text { lethal (\%) }\end{array}$} \\
\hline & Number & $\%$ & Number & Per female & Number & Per female & Number & Per female & & \\
\hline 0 & 5 & 83.3 & 39 & 7.8 & 39 & 7.8 & 0 & 0 & 0 & 0 \\
\hline 5 & 4 & 66.7 & 32 & 8 & 32 & 8 & 0 & 0 & 0 & 2.56 \\
\hline 10 & 5 & 83.3 & 43 & 8.6 & 43 & 8.6 & 0 & 0 & 0 & 10.26 \\
\hline 25 & 4 & 66.7 & 33 & 8.25 & 32 & 8 & 1 & 0.25 & 3.03 & 2.56 \\
\hline 50 & 3 & 50 & 19 & 6.33 & 19 & 6.33 & 0 & 0 & 0 & 18.85 \\
\hline CYpa & 4 & 66.7 & 32 & 8 & 31 & 7.75 & 1 & 0.25 & 3.13 & 0.64 \\
\hline
\end{tabular}

${ }^{a}$ CYP: cyclophosphamide (20 mg/kg); bead implants: number of early resorptions or moles.

OSL-treated male mice is presented in Table 3. The mating schedule was selected to represent OSL exposure covering the entire cycle of pre- and post-meiotic stages of spermatogenesis. All female mice from both control and OSL treated groups were considered in calculating percentage (\%) fertile mating considering that the frequency of infertility, notwithstanding OSL treatment, is expected to be the same. All females that had implants were regarded as "pregnant" and the number of implants, live embryos and dead implants per female (Figure 1B-1D) were determined based on pregnant females (Table 3). There were no dead implants $(0.0 \%)$ among females of the negative control mice and 5, 10, and 50\% OSL treatment, while 3.03 and $3.13 \%$ dead implants were observed among females mated using males exposed to $25 \%$ OSL and cyclophosphamide respectively. Using t-test there was no significant difference between the frequencies of pregnancy in female mice mated with the negative control and treated male mice (Table 3). Similarly, OSL did not induce significant pre- and post-implantation dominant lethal effects in female mice, only $25 \%$ OSL and cyclophosphamide treated male mice produced resorptions in the mated female and this was not statistically significant.

\section{Discussion}

Mixture of xenobiotics in OSL increased numerical and structural chromosomal aberrations in somatic and germ cells of eukaryotic organisms [6,11-13,27-29]. Chromosome aberrations have been implicated with mild to severe genetic and developmental disorders both in humans and wildlife [30]. Exposure to contaminants emitted from landfills has been described a risk factor in congenital anomalies, including Down syndrome, chromosomal congenital anomalies, fetal and neonatal deaths and developmental anomalies [2,31-33] among human population residing within 2-3 km circumference of landfill facilities. In this study, we hypothesized that OSL will increase abnormal sperm production in mice. Also, the out- come of mating between abnormal sperm morphology laden mice and normal nulliparous female mice will increase foetal/ neonatal death.

The murine sperm abnormality assay, capable of screening xenobiotics (mutagens, teratogens, and carcinogens) that can cause differentiation errors in spermatogenic stem cells [24,34], was used to screen OSL for germ cell genotoxicity. Significant increase in the frequency of abnormal sperm morphology induced in OSL treated mice signifies germ cell genotoxic effects of xenobiotics in the leachate [13,29]. It implies that the toxic metals and metalloids and other substances in the leachate (Table 1) interfered with the integrity of spermatogonia chromosomes and or expression of genes that stabilize the fidelity of DNA during spermatogenesis $[15,35]$. For instance, $\mathrm{Cu}$ and $\mathrm{Mn}$ are observed in the leachate, though they are essential elements which readily enhance normal functioning of enzymes and biological molecules but at high concentrations they can increase DNA damage by directly binding to sensitive molecules and or via free radical formation $[50,51]$. Also, $\mathrm{Pb}$ and $\mathrm{Cd}$ are metals that lack any biological relevance at threshold concentrations in the mammalian body, they can induce germ cell mutation and reproductive toxicity $[52,53]$. High concentrations of TDS, BOD, and COD in the leachate usually signal high organic pollutants in the leachate. This may corroborate our previous report wherein 23 different polycyclic aromatic hydrocarbons (PAHs) and polychlorinated biphenyls (PCBs) were analyzed in OSL [11]. The presence of these organic pollutants correlated with the induction of DNA damage and cytotoxicity in OSL-exposed human cell lines. The analyzed metals along with physico-chemical parameters and unanalyzed organic compounds in OSL individually and or interactively induced chromosome aberration and or DNA damage which occurred during mitotic and meiotic stages of spermatogenesis, and invariably resulted in the formation of abnormal sperm morphology $[34,36,54]$. Xenobiotics, including heavy metals, in OSL had similarly being reported to interfere with DNA integrity in spermatogonia nuclei of exposed 
boar [37] and peripheral erythrocytes and bone marrow polychromatic cells of fish, Japanese quail and rat $[6,12]$. These reports are in tandem with the observed abnormal sperms in the OSL-treated mice. Furthermore, that $47.68 \%$ of the total abnormal sperm cells in OSL-treated mice were with amorphous head (Figure 4) corroborated the report that human exposed to environmental toxicants including metals had higher teratozoospermia, high frequency of sperm cells with abnormal head morphology [38]. The observed impaired spermatogenesis in OSL-treated mice and humans exposed to environment toxicants were associated with free radical induced oxidative stress $[37,38]$.

Increase in the absolute and relative testes weight of OSL exposed mice suggests eodema [39]. While decrease in body weight of treated mice has been linked to OSL induced systemic toxicity $[7,19,20]$. Histopathology of the testes further revealed an evidence supporting OSL toxicity on the testes. For instance, spermatid retention observed in OSL treated mice corroborates the observed high abnormal sperm morphology $[40,41]$. Adequate blood supply to the testes is a requirement for active spermatogenesis and hormonal secretion [42]. Congestion of the interstitial blood vessel (Figure 6D) suggests that chemicals in OSL interrupted blood flow hence impairing spermatogenesis $[40,41]$. Depletion of spermatogonia, spermatocytes and spermatids, alterations in size and number of seminiferous tubules, reduction in germinal epithelium height and lumen space, and disorganization of the seminiferous tubules are lesions related to xenobiotic induced toxicity [39]. This is an indication that chemicals, most importantly metals, in landfill leachates can cross blood barrier to reach the testicular environment. Metals analyzed in OSL (Table 1) readily accumulate in testes and directly interfered with the tissue arrangement to produce pathological lesions [39]. Also, metals can indirectly inhibit growth and differentiation of spermatogonia via increase oxidative stress and lipid peroxidation. This will result in abnormal sperm morphology and chromosomal abnormalities in the primary spermatocytes $[43,44]$.

Teratozoospermia along with the other types of abnormal sperm shapes, are determinants in genetic heritability [24]. A human retrospective cohort study showed that a case of severe teratozoospermic condition caused low implantation and spontaneous term pregnancy rate and higher miscarriage rate when compared with patients with normal sperm morphology in an in vitro fertilization study [45]. The dominant lethal assay is a cytogenetic test used for regulatory testing of chemicals suspected to be mutagenic to germ cells. It detects alterations in genetic composition of germ cells via zygotic death produced before, during, or post-implantation [23]. This assay did not present significant difference between OSL-treated mice and the negative control mice in the percentage of postimplantation loss and increase mutagenic index. Although, there was reduced pregnancy outcome compared to the negative control, but this was not statistically significant. Considering that the highest selected concentration (50\%) of OSL induced $31.02 \%$ teratozoospermia in the treated male mice (Figure 3), it is possible that the remaining $69.98 \%$ of the normally produced spermatozoa fertilized the oocytes in the female mice. Since fertilization involves a random fusion of a sperm cell from among numerous ejaculated sperm cells with an oocyte, it is possible that the outcome of the dominant lethal test was due to the inability of any among the $31.02 \%$ teratozoospermia to fertilize the oocytes. This assertion lends credence to the report that in patients with $100 \%$ teratozoospermia and amorphous sperm head, there was complete failure during fertilization [45].

Although, the concentrations of OSL selected in this study significantly increased numerical and structural chromosome aberrations in somatic and germ cells of eukaryotic systems $[6,12,13,27,29]$. However, it seems that the abnormal sperm cells produced were not selectively favoured during fertilization in the study herein. This is because sperms with teratozoospermia and amorphous heads increase congenital anomalies, embryonic death, developmental disorders and / or other birth outcomes if fertilized viable oocytes [30]. Finding from the dominant lethal mutation test herein does not suggest a high risk of transmissible genetic damage from OSL-treated male mice. Therefore, the huge evidence of congenital anomalies, fetal and neonatal deaths and other developmental defects reported among infants born to women living near hazardous waste sites $[31,34,46]$ may not be totally linked to the exposure of men to landfill chemicals. The reports that $\mathrm{Cd}, \mathrm{Hg}$ and $\mathrm{Pb}$ increased chromosome aberration in bone marrow cells and abnormal sperm cells but did not significantly increase dominant lethality in rodents are in concert with our observation $[43,44,47,48]$. Considering that both male and female contribute equally to percentage infertility [49], we suggest that further studies on landfill leachate induced infertility, embryotoxicity and teratogenicity be carried out by mating non-treated males with leachate treated females and vice versa. This will enhance proper understanding of the role of sex in landfill induced infertility, embryotoxicity and teratogenicity. Furthermore, it is possible that selection of leachate concentrations that will increase the abnormal sperm morphology beyond $50 \%$ may results in significant dominant lethality.

In conclusion, the findings herein showed that OSL significantly increased abnormal sperm morphology and induced 
histopathological lesions in the testes of exposed mice. Also, OSL insignificantly increased absolute and relative testes weight and decreased body weight gain in mice. Sperm cells from leachate-treated male mice that fertilized oocytes from non-treated nulliparous females did not significantly increase spontaneous abortion, resorptions and post-implantation deaths. The findings suggest that the selected OSL concentrations and exposure duration, did not significantly induce dominant lethal mutations. It is therefore imperative to confirm whether congenital and developmental anomalies reported among residents in close proximity to landfill sites occur mainly due to defects during spermatogenesis, oogenesis and/or post fertilization events.

\section{CRidiT authors statement}

OJA: Experimental Investigation, Data analysis, WritingOriginal draft preparation; CGA: Conceptualization / Visualization of the study, Supervision, Data analysis, Writing- Original draft preparation, Reviewing and Editing; AAB: Supervision, Writing- Reviewing and Editing.

\section{Conflict of interest}

\section{Authors declare no form of conflict of interest exist.}

\section{References}

1. Giusti L. A review of waste management practices and their impact on human health. Waste Manag 2009;29(8):2227-2239.

2. World Health Organization (WHO) European Centre for Environment and Health (ECEH). Congenital anomalies. Fact sheet No. 370. 2014. [cited 2014 Oct 13] Available from: www.who.int/mediacentre/factsheets/fs370/en/

3. Njoku PO, Edokpayi JN, Odiyo JO. Health and environmental risks of residents living close to a landfill: A case study of Thohoyandou landfill, Limpopo Province, South Africa. Int J Environ Res Public Health 2019;16(12):2125.

4. Mills C. 15 of the world's largest landfills with photos and statistics. Updated on June 6, 2018. [cited 2019 Aug 12] Available from: https:// owlcation.com/stem/15-of-the-Worlds-Largest-Landfills.

5. Olorunfemi FB. Landfill development and current practices in Lagos metropolis, Nigeria. J Geogr Reg Plan 2011;4(12):656-663.

6. Alimba CG, Bakare AA, Latunji CA. Municipal landfill leachates induced chromosome aberration in rat bone marrow cells. Afr J Biotechnol 2006;5(22): 2053-2057.

7. Alimba CG. DNA and systemic damage induced by landfill leachates and health impacts of human exposure to landfills in Lagos and Ibadan, Nigeria. [Ph.D dissertation]. Ibadan, Nigeria: University of Ibadan;2013

8. Ogundiran OO, Afolabi TA. Assessment of the physicochemical parameters and heavy metals toxicity of leachates from municipal solid waste open dumpsite. Int J Environ Sci Tech 2008;5(2):243-250.
9. Ademola AK, Olaoye MA, Abodunrin PO. Radiological safety assessment and determination of heavy metals in soil samples from some waste dumpsites in Lagos and Ogun State, South-western, Nigeria. J Radiat Res Appl Sci 2015;8(1):148-153.

10. Aboyeji OS, Eigbokhan SF. Evaluations of groundwater contamination by leachates around Olusosun open dumpsite in Lagos metropolis, southwest Nigeria. J Environ Manag 2016;183:333-341.

11. Alimba CG, Gandhi D, Sivanesan S, Bhanarkar MD, Naoghare PK, Bakare AA, et al. Chemical characterization of simulated landfill soil leachates from Nigeria and India and their cytotoxicity and DNA damage inductions on three human cell lines. Chemosphere 2016; 164:469-479.

12. Alimba CG, Bakare AA. In vivo micronucleus test in the assessment of cytogenotoxicity of landfill leachates in three animal models from various ecological habitats. Ecotoxicol 2016;25(2):310-319.

13. Bakare AA, Mosuro AA, Osibanjo O. An in vivo evaluation of induction of abnormal sperm morphology in mice by landfill leachates. Mutat Res 2005;582(1-2):28-34.

14. Atienzar FA, Cheung VV, Jha AN, Depledge MH. Fitness parameters and DNA effects are sensitive indicators of copper-induced toxicity in Daphnia magna. Toxicol Sci 2001;59(2):241-250.

15. Schulte RT, Ohl DA, Sigman M, Smith GD. Sperm DNA damage in male infertility: etiologies, assays, and outcomes. J Assist Reprod Genet 2010;27(1):3-12.

16. Brender JD, Maantay JA, Chakraborty J. Residential proximity to environmental hazards and adverse health outcomes. Am J Public Health 2011;101(S1):S37-S52.

17. Attia SM, Ahmad SF, Okash RM, Bakheet SA. Dominant lethal effects of nocodazole in germ cells of male mice. Food Chem Toxicol 2015;77: 101-104.

18. Lagos State Waste Management Authority (LAWMA). 2011. [cited 2015 Jan 24] Available from: www.lawma.gov.ng/lawma_lanfill.html

19. Alimba CG, Onajole AI, Bakare AA. Brain dysfunction in Wistar rats exposed to municipal landfill leachates. Beni-Suef Uni J Basic Appl Sci 2015;4:284-290.

20. Alimba CG, Bakare AA, Aina OO. Liver and kidney dysfunction in Wistar rats exposed to municipal landfill leachate. Resour Environ 2015; 2(4):150-163.

21. United States Environmental Protection Agency (USEPA). Acid digestion of sediments sludges and soils, Method-3050B. 1996.

22. American Public Health Association (APHA). Standard methods for the examination of water and wastewater. 20th ed. Washington DC: American Public Health Association (APAHA, AWWA, WPCF); 1998.

23. Organisation of economic co-operation and development (OECD). Revised guidelines for testing chemicals No 478. The dominant lethal assay, Paris. 2013. Available from: http://www.oecd.org/chemicalsafety.

24. Wyrobek AJ, Gordon LA, Burkhart JG, Francis MC, Kapp Jr. RW, Letz G, et al. An evaluation of the mouse sperm morphology test and other sperm tests in non-human mammals. A report of the U.S. Environmental Protection Agency Gene-Tox Program. Mutat Res 1983;115(1): $1-72$.

25. National Environmental Standards and Regulation Enforcement Agency (Federal Republic of Nigeria Official Gazette). National environmental (sanitation and waste control). Abuja FGP 112/102009/ L000 (OL54). No.60 (96); 2009, p. 1057-1102. 
26. United States Environmental Protection Agency (USEPA). Maximum permissible limit for effluents from wastewater. 2006. Available from: http://www.epa.gov/safewater/mcl.html

27. Sang N, Li G. Chromosomal aberrations induced in mouse bone marrow cells by municipal landfill leachate. Environ Toxicol Pharmacol 2005;20(1):219-224.

28. Klauck CR, Rodrigues MAS, da Silva LB. Toxicological evaluation of landfill leachate using plant (Allium cepa) and fish (Leporinus obtusidens) bioassays. Waste Manag Res 2013;31(11):1148-1153.

29. Shekha YA, Al-Attar MS, Saleem MA, Toma JJ, Abdulla SM. Effect of landfill leachates extract of Erbil city on abnormal sperm morphology and chromosomal aberrations in male albino mice. ZANCO J Pure Appl Sci 2017;29(6):18-27.

30. Theisen A, Shaffer LG. Disorders caused by chromosome abnormalities. Appl Clin Genet 2010;3:159-174.

31. Jarup L, Morris S, Richardson S, Briggs D, Cobley N, de Hoogh C, et al. Down syndrome in births near landfill sites. Prenat Diag 2007;27(12): 1191-1196.

32. Vrijheid M, Dolk H, Armstrong B, Boschi G, Busby A, Jorgensen T, et al. Hazard potential ranking of hazardous waste landfill sites and risk of congenital anomalies. Occup Environ Med 2002;59(11):768-776.

33. Gilbreath S, Kass PH. Fetal and neonatal deaths and congenital anomalies associated with open dumpsites in Alaska Native villages. Int J Circumpolar Health 2006;65(2):133-147.

34. Marchetti F, Wyrobek AJ. Mechanisms and consequences of paternally transmitted chromosomal abnormalities. Birth Defects Res Part C Embryo Today. 2005;52.

35. Adamkovicova M, Toman R, Martiniakova M, Omelka R, Babosova R, Krajcovicova V, Grosskopf B, Massanyi P. Sperm motility and morphology changes in rats exposed to cadmium and diazinon. Reprod Biol Endocrinol 2016;14: 42.1-7.

36. Kishikawa H, Tateno H, Yanagimachi R. Chromosome analysis of BALB/c mouse spermatozoa with normal and abnormal head morphology. Biol Reprod 1999;61(3):809-812.

37. Adedara IA, Oyebiyi OO, Lawal TA, Adesina AA, Farombi EO. Involvement of oxidative stress in municipal landfill leachate-induced toxicity in boar sperm. Environ Toxicol Pharmacol 2013;36(3):972-978.

38 Turner TT, Lysiak JJ. Oxidative stress: a common factor in testicular dysfunction. J Androl 2008;29(5):488-498.

39. Hirai S, Hatayama N, Naito M, Nagahori K, Kawata S, Hayashi S, et al. Pathological effect of arterial ischaemia and venous congestion on rat testes. Sci Rep 2017;7:5422.

40. Lanning LL, Creasy DM, Chapin RE, Mann PC, Barlow NJ, Regan KS, et al. Recommended approaches for the evaluation of testicular and epididymal toxicity. Toxicol Pathol 2002;30(4):507-520.

41. Creasy DM. Evaluation of testicular toxicology: a synopsis and discussion of the recommendations proposed by the Society of Toxicologic Pathology. Birth Defects Res B Dev Reprod Toxicol 2003;68(5):408415.

42. Bollwein H, Schulze JJ, Miyamoto A, Sieme H. Testicular blood flow and plasma concentrations of testosterone and total estrogen in the stallion after the administration of human chorionic gonadotropin. J Reprod Dev 2008;54(5):335-339.

43. Kumar TR, Doreswamy K, Shrilatha B, Muralidhara. Oxidative stress associated DNA damage in testis of mice: induction of abnormal sperms and effects on fertility. Mutat Res 2002;513(1-2):103-111.

44. Asadi N, Bahmani M, Kheradmand A, Rafieian-Kopaei M. The impact of oxidative stress on testicular function and the role of antioxidants in improving it: a review. J Clin Diagn Res 2017;11(5):IE01-IE05.

45. Tasdemir I, Tasdemir M, Tavukcuoglu S, Kahraman S, Biberoglu K. Effect of abnormal sperm head morphology on the outcome of intracytoplasmic sperm injection in humans. Hum Reprod 1997;12(6):12141217.

46. Dodds L, Seviour R. Congenital anomalies and other birth outcomes among infants born to women living near a hazardous waste site in Sydney, Nova Scotia. Can J Public Health 2001;95(5):331-334.

47. Khan AT, Atkinson A, Graham TC, Thompson SJ, Ali S, Shireen KF. Effects of inorganic mercury on reproductive performance of mice. Food Chem Toxicol 2004;42(4):571-577.

48. Selby PB, Earhart VS, Douglas Raymer GD. The influence of dominant lethal mutations on litter size and body weight and the consequent impact on transgenerational carcinogenesis. Mutat Res-fund Mol Mech Mutat 2005;578(1-2):382-394.

49. Karaca N, Akpak YK, Oral S, Durmus T, Yilmaz R. A Successful healthy childbirth in a case of total globozoospermia with oocyte activation by calcium ionophore. J Reprod Infertil 2015;16(2):116-120.

50. Roychoudhury S, Nath S, Massanyi P, Stawarz R, Kacaniova M, Kolesarova A. Copper-induced changes in reproductive functions: in vivo and in vitro effects. Physiol Res 2016:11-22.

51. Silva APG, Santiago MSA, Maranho LA, Oliveira RP, Constantino DHJ, Pereira CDS, et al. Could male reproductive system be the main target of subchronic exposure to manganese in adult animals? Toxicol 2018; 409:1-12.

52. Zhao L, Ru Y, Liu M, Tang J, Zheng J, Wu B, et al. Reproductive effects of cadmium on sperm function and early embryonic development in vitro. PLoS ONE 2017:12(11).

53. Anjum MR, Sainath SB, Suneetha Y, Reddy PS. Lead acetate induced reproductive and paternal mediated developmental toxicity in rats. Ecotoxicol Environ Saf 2011:74(4):793-799.

54. Fagbenro OS, Alimba CG, Bakare AA. Experimental modeling of the acute toxicity and cytogenotoxic fate of composite mixtures of chromate, copper and arsenate oxides associated with CCA preservative using Clarias gariepinus (Burchell 1822). Environ Anal Health Toxicol 2019;34(3):e2019010.

55. Krishna G, Petrere J, Anderson J, Theiss J. Use of cyclophosphamide as a positive control in dominant lethal and micronucleus assays. Mutat Res/Environ Muta Relat Sub 1995; 335(3):331-337.

56. Chamorro-Cevallos G, Garduno-Siciliano L, Barron BL, Madrigal-Bujaidar E, Cruz-Vega DE, Pages N. Chemoprotective effect of Spirulina (Arthrospira) against cyclophosphamide-induced mutagenicity in mice. Food Chem Toxicol 2008;46(2):567-574 